\title{
ТВОРЧО-ОРГАНІЗАЦІЙНІ ПРИНЦИПИ ДІЯЛЬНОСТІ МІЖНАРОДНОГО ТЕАТРАЛЬНОГО ФЕСТИВАЛЮ «МЕЛЬПОМЕНА ТАВРЇ̈»
}

У статті досліджуються творчо-організаційні аспекти діяльності одного з провідних та найстаріших фестивалів в Украйні - Міжнародного театрального фестивалю «Мельпомена Таврії». Коротко розглядається поняття фестивалю як організаційно-художньої форми, яка є серію демонстраційних публічних показів рівня майстерності (досягнень), підпорядкованих наскрізній мистецькій ідеї або концепиії, локалізованих в обмежений календарний період в певному географічному і культурному просторі; його соиіокультурна функиія. Аналітичному вивченню піддається статистика географії учасників, організація роботи журі та результати конкурсу. Головна увага приділена аналізу репертуарної та номінаційної політики «Мельпомени Таврії».

Ключові слова: фестиваль-конкурс, Міжнародний театральний фестиваль «Мельпомена Таврії», фестивальний репертуар, номіначійна політика.

В статье рассматриваются творческо-организаиионные аспекты деятельности одного из ведущих и старейших театральных фестивалей в Украине - Международного театрального фестиваля «Мельпомена Таврии». Коротко характеризуется понятие фестиваля как организачионно-художественной формы, которая представляет собой серию демонстращионных публичных показов уровня мастерства (достижений), подчиненных сквозной художественной идее или концепции, локализованных в ограниченный календарный период в определенном географическом и культурном пространстве; его сочиокультурная функиия. Аналитическому изучению поддаётся статистика географии участников, организачия работы жюри и результаты конкурса. Главное внимание уделено анализу репертуарной и номиначионной политики «Мельпомень Таврии».

Ключевые слова: фестиваль-конкурс, Международный театральный фестиваль «Мельпомена Таврии», фестивальный репертуар, номинации.

The article refers to the creative and organizational aspects of one of the leading and oldest festivals in Ukraine - the International Theatre Festival «Melpomena Tavrii». Analytical study is applied to sociocultural function of the festival, stats of geography of the participants, organization of jury's work and contest results. The main focus is on analysis of nominating and repertoire policies of «Melpomena Tavrii».

Keywords: festival-competition, the International Theatre Festival «Melpomena Tavrii» festival repertoire, nominating policy.

У сьогоднішньому світі відбуваються масштабні глобалізаційні процеси, ознакою яких стала політична, економічна і культурна інтеграція. Стає чимдалі більш зрозумілим, що ізоляція шкідлива на всіх рівнях — від самоізоляції особи і окремого колективу до цілих держав і народів. Культурний обмін надає можливість ефективніше пізнати і зрозуміти одне одного. Сьогодні культурне співробітництво стає рушієм цивілізаційного прогресу і тому набуває дедалі більшої ак- туальності. Співпраця в галузі культури включає виставки, вистави, концерти, презентації, зустрічі 3 відомими діячами культури, науково-практичні конференції, гастрольну діяльність українських колективів, а також театрально-фестивальні форми. Театральне мистецтво як складова національної української культури сприяє подоланню соціокультурних кордонів.

Останні десятиліття позначені інтенсифікацією фестивального руху в Україні, зумовлено- 
го багатьма факторами в тому числі поступовою трансформацією соціокультурного простору. Означений процес відбувається як в столиці держави, так і в регіонах.

Виховна та культурно-мистецька роль фестивалів у суспільстві надзвичайно велика. Під час їхньої підготовки і проведення значно пожвавлюється культурне життя, забезпечується залучення людей до культурних цінностей, розширюється культурна інфраструктура. У зв'язку з цим сьогоднішній бурхливий розвиток театральних фестивалів, специфіка існування цього феномену в соціокультурному контексті, з'ясування причин його поширення і перетворення на самостійний i самодостатній чинник театрального процесу потребує наукового осмислення.

Вибір теми цього дослідження визначений тією увагою, що приділяється зростаючій кількості театральних фестивалів на теритоpiї України, серед яких одне з чільних місць посідає Міжнародний театральний фестиваль «Мельпомена Таврії», що проводиться щорічно у Херсоні. Захід було задумано як всеукраїнський фестиваль прем'єр музичних вистав, але з роками він розширив свої жанрові та географічні кордони. Наразі в ньому беруть участь професійні театральні колективи України, близького і далекого зарубіжжя.

Мета нашої наукової розвідки передбачає 3'ясування специфіки творчо-організаційної діяльності Міжнародного театрального фестивалю «Мельпомена Таврії».

Про затребуваність суспільством такої тематики свідчить неабиякий інтерес вітчизняних театрознавців до проблеми фестивального театрального руху в Україні та визначення місця окремих фестивалів у контексті культурно-мистецького життя країни, адже фестивалі, як засвідчує світовий та український досвід, визначають напрямки розвитку мистецтва, продукують нові ідеї та відкривають нові обрії творчої діяльності. При цьому поняття фестиваль розглядається як організаційно-художня форма, яка є серією демонстраційних публічних показів рівня майстерності (досягнень), підпорядкованих наскрізній художній ідеї або концепції і локалізованих в обмежений календарний період в певному географічному і культурному просторі. Особливості проведення театральних фестивалів в Україні дістали висвітлення у працях М. Близнюк, О. Доманської, О. Литовки, Г. Хромої та ін. Але аналіз літератури, пов'язаної 3 темою дослідження Міжнародного театрального фестивалю «Мельпомена Таврії» у контексті фестивального руху, засвідчує, що наукового теоретично-історичного осмислення цього явища як актуальної мистецької та соціокультурної форми не проводилось.

Будь-який фестиваль ставить на меті відкриття нових талантів. Протягом останнього десятиліття проводилось чимало різножанрових міжнародних і всеукраїнських театральних фестивалів, у яких взяли участь театри України та зарубіжні театральні колективи. Суспільний інтерес до театральних фестивалів пояснюється в основному наданням можливості любителям театру побачити нові вистави в один і той самий час, познайомитися 3 маловідомими тенденціями, зустрітися 3 представниками різних театральних колективів.

Кожен фестиваль має свою художню концепцію. Вона являє собою не суму якихось абстрактних естетичних, соціальних, економічних установок, а модель стійкої, систематично спрямованої практичної репертуарної політики та орієнтації на певні категорії глядачів і слухачів, які визначають статус даного фестивалю серед інших. Художня концепція формується 3 урахуванням всіх різноманітних просторово-часових характеристик фестивалю, традицій і вже наявних форм i напрямів мистецького життя. Художня концепція реалізується у видовій, жанровій і тематичній спрямованості кожного фестивалю. За видовою спрямованістю в області виконавських мистецтв розрізняють музичні, театральні та багатопрофільні фестивалі. Перші дві групи включають все історичне різноманіття музичних і театральних жанрів і форм, хоча всередині групи можлива більш вузька спеціалізація. $\mathcal{C}$ велика кількість моножанрових театральних фестивалів.

Театральні форуми в містах України мають свою специфіку. Фахівці користуються такою класифікацією фестивалів:

- За часом проведення: короткострокові (одноденні; ті, що проходять в кілька днів; тижневі фестивалі); середньострокові (від двох тижнів до одного місяця); довгострокові (що йдуть місяць і більше та/або потребують тривалої підготовки 3 питань організації).

- За місцем організації та відповідної локалізації: стаціонарні - відбуваються в одному і тому ж місті (місці); мобільні, що проходять на різних майданчиках, в різних містах і навіть країнах.

- За наявністю змагальної складової: орієнтація на консолідацію людей, пов'язаних одним родом діяльності, і виявлення загальних тенденцій у театральному мистецтві (фестиваль-огляд, 
фестиваль-демонстрація); відкрита форма змагання з метою виявити найкращого, еталонного представника (конкурс-фестиваль).

- За географією учасників: локальні (районні, міські, обласні); республіканські; міжнародні.

Якщо користуватися запропонованою фестивальною систематизацією, то Міжнародний театральний фестиваль «Мельпомена Таврії» можна віднести до категорії середньострокових, стаціонарних, міжнародних фестивалів-конкурсів.

Фестиваль було започатковано на Херсонщині у червні 1999 року в межах святкування Дня міста. Він проводиться щороку в травні-червні на базі Херсонського обласного академічного музично-драматичного театру імені Миколи Куліша та Херсонського театру ляльок. Основна мета фестивалю-конкурсу - популяризація театрального мистецтва, підйом його авторитету, обмін досвідом між творчими колективами, ознайомлення глядача 3 музичними театральними прем'єрами і визначними досягненнями театрів різних регіонів України і країн зарубіжжя.

Засновниками і організаторами фестивалю $є$ ТОВ «Фестивальний центр», Херсонський обласний академічний музично-драматичний театр імені Миколи Куліша. Фестиваль проходить за підтримки Міністерства культури України, Національної спілки театральних діячів України, Херсонської обласної державної адміністрації та Херсонського міськвиконкому.

До складу журі фестивалю-конкурсу входять провідні театральні діячі, театрознавці й театральні критики України. Журі фестивалю має два склади - професійне та альтернативне (журналістське). Оскільки обидва склади суддів мають право вручати нагороди переможцям фестивалю і подекуди їхні рішення різняться, то диплом переможця у певних номінаціях, хоч як це парадоксально, за рішенням кожного журі може присуджуватись одночасно двом різним претендентам.

Для вивчення сутності і впливу на театральне мистецтво України будь-якого театрального фестивалю слід розуміти, які саме мистецькі твори репрезентуються на цьому форумі, їхне жанрове розмаїття, дотримання чи не дотримання певного стильового напряму представлених вистав - все це і становить репертуарну політику фестивалю. 3 метою відтворення історичної правди потрібно визначити, чи змінювалась ця політика за період існування фестивалю: чи фестиваль розвивається і прогресує, чи він тяжіє до консерватизму, стабільності і традиційності в своїх творчо-організаційних засадах.
Для характеристик репертуарної політики «Мельпомени Таврії» слід звернутись до історії розвитку фестивалю.

Від 1999 року - року заснування - протягом 5-ти років фестиваль успішно існував як конкурс музичних прем'єр. У 1999 році на ньому була представлена ексцентрична комедія «За двома зайцями» М. Старицького Донецького державного академічного українського театру ім. Артема вистава-переможець колись відомих і популярних фестивалів «Театральний Донбас» та «Прем'єри сезону», котрий поєднує виразну музику, запальні танці та соковитий народний гумор. Також у репертуарі фестивалю були представлені вистави за творами П.Зюскінда (Київський театр на Липках), А.Стріндберга (Львівський театр «Воскресіння»), П.Бомарше (Херсонський обласний академічний музично-драматичний театр ім. М. Куліша), музично-драматична комедія Миколаївського академічного українського театру драми та музичної комедії «Марні зусилля кохання» за В.Шекспіром, вистава-фентезі «Верона» за Г. Горіним Миколаївського російського драматичного театру ім. Чкалова. Таким чином, на першому фестивалі перевагу віддавали виставам за творами класичної драматургії, а $85 \%$ учасників становили академічні театри, і лише одна вистава була представлена від експериментального театру.

У 2000 році збереглася тенденція до тяжіння в репертуарі фестивалю класичних творів, але умовою участі для колективів залишається наявність музичності у представлених спектаклях. Тут презентуються вистави за творчістю Г. Квітки-Основ'яненка, Й.Штрауса, В.Висоцького, Я.Стельмаха, Лесі Українки. Але, окрім вистав класичного драматичного спрямування, на фестивалі вперше з'являється Криворізький приватний театр пластики «Академія руху» під керівництвом Галини Костенко 3 виставою «Квітень у новорічну ніч», який пізніше 3'являтиметься на конкурсі майже не щороку і приємно дивуватиме своїми напрацюваннями в сфері пластичного театру.

Наступного року фестивальний репертуар починає поступово відходити від обов'язковості ідеї свого музичного спрямування, і в ньому 3'являються вистави, які жанрово не потрапляють до розряду «музичних». Йдеться про моноспектакль «Клоунеса Таміла» Кейчі Нісіди — українсько-японський проект у режисурі В. Крюкова та у виконанні Т. Петрощук. «Лісову пісню» Херсонського театру теж важко було назвати суто музичною, скоріше видовищною, де музика допомагала створити феєрію з елементами шоу. Отже, 
окрім академічних драматичних театрів у фестивалі беруть участь вже два пластичних театри (Київський театр пластики Володимира Крюкова та Криворізький театр «Академія руху») [1].

Під час проведення IV фестивалю можна було споглядати тенденційне розширення жанрових рамок, у програмі дедалі частіше починають 3'являтися експериментальні театри. Поряд з виставами, представленими обласними драматичними театрами за творами М. Куліша, А. Гофмана, Г. Горіна, Д. Германа, у фестивальній афіші бачимо оперу-зінгшпіль «Директор театру», написану В.А. Моцартом на лібрето Г. Штефані, котру представило Одеське міжрегіональне відділення НСТД України; експериментальний театр КиєвоМогилянської академії, а також пластичну виставу «Сліпі» за п’єсою М. Метерлінка Київського театру пластики Володимира Крюкова [2].

У 2003 році на фестиваль вперше приїздять колективи із зарубіжжя, але ні театр із Білорусі, ані ансамбль 3 Росії до професійного театрального мистецтва не мають особливого стосунку. Із білоруського міста Лепель приїздить народний театр «Пошук» 3 виставою «За двома зайцями», а з Москви - експериментальний ансамбль Дмитра Покровського 3 концертом фольклорної музики «Від фольклору до авангарду». Тобто перші спроби організаторів театру запросити на фестиваль учасників із закордону хоч і з якісним, а подекуди і з всесвітньо відомим (ансамбль Д. Покровського) репертуаром, все ж таки дають і не зовсім позитивні плоди. Адже постає питання: чи $\epsilon$ «Мельпомена Таврії» фестивалем саме професійних театрів, адже на одних підмостках змагаються професійні і аматорські колективі, та чи не знижують організатори критерії відбору, змішуючи в єдиній конкурсній програмі різні жанри театрального мистецтва. I чи є, наразі, цей фестиваль взагалі «театральним», якщо в програмі, окрім зразків власне мистецтва театру, вочевидь присутні приклади мистецтва естради?

Більш того, справляється враження, ніби для оргкомітету не був принциповим відбір матеріалу від закордонних учасників, якщо він узагалі проводився, а головною метою стало набуття для фестивалю статусу «міжнародного». Однак для такого молодого фестивалю на той час присутність серед учасників іноземних колективів, які так чи інакше пов'язані зі сценічним мистецтвом, вже було великим досягненням і першим кроком для кардинального розширення власних кордонів.

Слід відзначити ще одного тогорічного учасника форуму, який, хоч і вписувався у формат му- зичності, однак виходив за межі суто театрального жанру, оскільки у виставі домінували естрадні елементи. Це був спектакль Майстерні театрального мистецтва «Сузір'я» «В Барабанном переулке» за творчістю Б. Окуджави. Жанр вистави визначено як вокальну історію у 27 картинах, що сплетена з 27 пісень відомого барда, поданих в естрадному жанрі зримої пісні. Добре знані, ті, що в усіх на слуху, пісні Окуджави склались у любовну історію, котра розігрується у привокзальному буфеті під акомпанемент тапера.

У 2004 році у своєму інтерв'ю для журналу «Український театр» директор фестивалю О. Книга, виправдовуючи відмову від ідеї проведення фестивалю музичних прем'єр, аргументує свою позицію тим, що музичному театрові виїздити на фестивалі організаційно дуже-дуже складно, бо кожна вистава - масова.

Таким чином, в репертуарі фестивалю не залишається пріоритетної жанрової, стильової чи естетичної особливості і він остаточно перетворюється в огляд найцікавіших, на думку оргкомітету, знахідок театру вже не лише різних областей України, а й куточків близького, а в майбутньому і дальнього зарубіжжя.

Театри продовжують привозити вистави за творами М.Куліша, Г. Горіна, А. Крима. Деяким 3 них вдається стилізувати класичного автора, поекспериментувати 3 матеріалом ще й отримати за це нагороду, як, скажімо, «Театру 19» із Харкова за виставу «Хулія славлю» (М. Куліш). Традиційним стає відвідування фестивалю Театром на ходулях Києво-Могилянської академії. Позитивні відгуки преси отримують вистави театру «Сузір'я» (м. Київ) «Парнас дибки» - за творами Юрія Олеші, Анни Ахматової, Володимира Маяковського, Миколи Заболоцького, Семена Кірсанова, Іллі Ільфа і «Шельменко-денщик» Херсонського театру. Камерною виставою кияни презентували глядачам сцени життя літераторів на відпочинку в стилі джазової імпровізації 30 -х років XX ст. у постановці І. Славинського (нагорода «За кращу режисуру»). А знаменита комедія Г. КвіткиОснов'яненка «Шельменко-денщик» у постановці Анатолія Канцедайла отримала оригінальне рішення (нагорода «За прочитання класики»). Успіху вистави сприяли іiі сценографія, яскраві стилізовані костюми, акторський ансамбль, оригінальне пластичне і музичне рішення $[3,7]$.

На сьомому році існування фестивальний репертуар розширюється появою в програмі лялькової вистави («Нам не страшен серый волк» Херсонського обласного театру ляльок), цигансько- 
го мистецтва (Київський державний циганський музично-драматичний театр «Романс» 3 виставою «Легенда про скрипку»). В афіші також продовжують про себе заявляти представники аматорського театрального мистецтва (Народний молодіжний театр «Шанс» 3 виставою «Панночка» 3 м. Нова Каховка). Одеське міжрегіональне відділення НСТД України продовжує презентувати театр малої форми (вистава «Акомпаніатор» за твором М. Мітуа), а Криворізький театр музично-пластичних мистецтв «Академія руху» 3 виставою «Реквієм» відстоює позиції театру пластики [4].

Театрознавець Л.Шевченко відзначає, що у 2006 році у діапазоні фестивалю наявні музично-драматичні постановки, і рок-опери, і оперети, пластичні, драматичні спектаклі, моновистави. Того року за сім днів на двох сценах — театру ім. М. Куліша та Театру ляльок - було показано 17 вистав. Більшість порушували філософсько-етичні питання: людська особистість і сенс життя; людина і суспільство, цінності удавані та справжні, руйнівна сила війни, звучала тема кохання і творчості як способу існування. Були i вистави відверто розважального характеру $[5,41]$.

Отож серед представлених вистав за жанровими характеристиками вирізняємо: пластичну драму («Безсоння» за мотивами творів Т. Шевченка Криворізького театру «Академія руху» та виставу «Прощавай, Моцарте, або Знову Сальєрі» Київського театру пластичної драми на Печерську); рок-оперу («Одвічна пісня» Республіканського театру білоруської драматургії з м. Мінська); драматичну баладу («Не покидай мене» Московського драматичного театру на Перовській); притчу про кохання і смерть («Співав соловей, бузок цвів» за п'єсою О. Селіна Московського Нового драматичного театру); оперету («Фіалка Монмартру» I. Кальмана Херсонського академічного театру ім. М. Куліша); виставу-сповідь (вокально-драматичне прочитання поетично-пісенної творчості В.Висоцького у поєднанні зі спогадами М. Владі у виставі «Иноходец» театру Романс-хол Володимира Засухіна з Києва); моновиставу (за повістю І. Нечуя-Левицького «Кайдашева сім'я» Дніпропетровського театру ім. Т. Шевченка); сповідь актриси кабаре у просторі («Vaya con Dios»«Кабаре Бухенвальд» Клима Запорізького театру-лабораторії «VIE» 3 о. Хортиця); мюзикл («У джазі лише дівчата» О. Аркадіна-Школьника i Є.Кулакова за мотивами кінострічки Біллі Вайлдера Донецького академічного українського муздрамтеатру); містичну драму («Трійка, сімка, туз» М. Коляди за мотивами твору О.Пушкіна
«Пікова дама» Кишинівського муніципального театру-студії «3 вулиці Роз») та інші [6].

Програма «Мельпомени Таврії-2006» свідчить, на думку Л. Шевченко, що звернення до класики і спроба через асоціації та аналогії висвітлювати сьогодення - не випадкові. Вона пов'язує це з відсутністю досконалої сучасної драматургії $[5,43]$.

У 2007 році у фестивальній програмі продовжує панувати суміш жанрів та форм. Серед театрів-учасників домінують академічні драматичні театри, однак разом 3 ними у фестивалі беруть участь Київський театр-студія Молодіжний інтерактивний сучасний театр (МICT) з виставою «Той, що відчиняє двері» Н. Нежданої, Чернігівський обласний молодіжний театр 3 виставою «Тартюф» за Ж.-Б. Мольєром, Луганський театр пісні і танцю «Легенда» $з$ виставою «Ми твої, Вкраїно, козаки».

Наступного року в репертуарі фестивалю особливо акцентувалася пластика, про що свідчать такі постановки, як «Ромео і Джульєтта» («Академія руху»), «У полоні Кармен» (Київський Молодий театр), концерт 3 проекту «Нащадки Марселя Марсо», вистави «Дощ» та «Болеро» (Київ модерн-балет), «Червоні вітрила» (Херсонський театр ім. М. Куліша). А. Погрібна та О. Велимчаниця зазначають, що різноманіття жанрів - це яскрава особливість фестивалю [7, 44]. А Л. Распутіна вважає, що у всьому розмаїтті стилів, жанрів і видів мистецтва в «Мельпомені Таврії» є ритм, смак і певний рівень культури $[8,15]$

XI фестиваль був присвячений 200-річчю 3 дня народження Миколи Гоголя, проте організатори не обмежувалися лише інсценізаціями класика і глядачі мали нагоду оцінити й інші роботи. Багатожанровість заходу доповнила моноопеpa, яка була вперше представлена в рамках фестивалю, а саме «Очікування» М. Таривердієва. Виконувала іiі солістка Одеського національного театру опери та балету Ірина Красиліна, фортепіано - Ольга Єфремова. Однак ця вистава не отримала високої оцінки у критиків і глядачів, адже солістка опери не володіє достатньою акторською майстерністю, щоб затримати увагу глядача. Тому глядачеві залишалося насолоджуватись лише гарною музикою Таривердієва та хорошим професійним співом, а для театру - як явища синтетичного, на думку О. Велимчаниці, цього замало. Адже йдеться саме про театральний фестиваль, а не конкурс вокального чи оперного мистецтва.

Того року на фестивалі було представлено також непрофесійні та студентські театри: Мурманський народний драматичний театр «Комедіограф», Перший український жіночий 
«Театр на Грушках» і Румунський театр «Ateneu», але серед них чомусь лише вистава «Театру на Грушках» не брала участь в основному конкурсі. Інші два театри нагороди на фестивалі отримали.

Театрознавець С.Шашко критично заявила, що за всієї строкатості жанрів, форм, різноадресності показаних спектаклів, більшість учасників «Мельпомени Таврії» засвідчили тенденцію сучасної режисури до вправного володіння ремеслом: домінування яскравої театральної форми над глибинністю змісту, вміння організувати атмосферу дійства (світло, музика, пластичне рішення, вокал), обходячи філігранність акторських образів [9, 143].

Після фестивалю, проведеного у 2010 році, у деяких театрознавців і журналістів виникло масове побажання до організаторів ретельніше відбирати вистави-учасникці. С. Максименко говорить про те, що на фестивалі наявні й драматичний, i музичний, i музично-пластичний, i ляльковий, і студентський, і експериментальний, і монотеатр. Тому оргкомітетові слід було б чіткіше визначати творче спрямування та програму фестивалю заради загальної результативності - адже не всі вистави вдається переглянути через їхню велику кількість. О. Книга, в свою чергу, виправдовує такий мистецький пресинг, зауважуючи, що він $\epsilon$ своєрідною альтернативою невеселій картині недавнього минулого Херсона, коли у залі глядачів було іноді менше, ніж акторів на сцені $[10,210]$.

Отже насичення фестивального репертуару виставами в найрізноманітніших жанрах та театрами різних напрямів продовжується. У 2011 р. на фестиваль приїздить Кіровоградський шоу-театр молодіжного клубу «Імідж», а в 2012 р. у програмі з'являється ще й документальний театр Центр документальної п'єси VERBATIM з виставою «Матки-Душі» (О. Луненок). Театрознавець O. Велимчаниця оцінює XIV фестиваль як захід, відкритий до нових театральних форм та напрямів, до нових колективів та імен. Однак знову ж висловлюється побажання, щоб «Мельпомена Таврії» не цуралась ретельного відбору, оскільки чимало вистав, представлених у 2012 р., не дотягували до рівня міжнародного фестивалю $[11,40]$.

У 2013 р. організатори, ніби згадуючи витоки «Мельпомени Таврії» 3 фестивалю музичних прем'єр, насичують репертуар мюзиклами, а вистави, окрім традиційних театральних приміщень, відбуваються просто неба, на березі Дніпра та в лісі $[12,51]$.

У 2014 р., зважаючи на суспільно-політичну ситуацію в Україні, більшість представлених спектаклів були драматичними або трагедійни- ми. Практично не було комедій і мелодрам. На фестивалі традиційно була широко представлена класика: Тарас Шевченко, Микола Гоголь, Іван Кочерга, Михайло Булгаков, Генрік Ібсен, Теннесі Вільямс тощо $[13,44]$. На XVII фестивалі в програмі з'являється ще й телевізійний театр Дніпропетровський міський телевізійний театр 3 виставою «Ніч Святого Валентина» (О. Мардань), а на останньому, найбільшому за історію існування, фестивалі, окрім традиційного різнобарв'я жанрів, представили свої роботи Міжнародна антинаркотична асоціація («Останній вагон» Т.Жирка), «Quartet DEKRU» - 3 пластично-візуальним шоу «Light Souls», Львівський театр естрадних мініатюр з виставами «І люди, і ляльки» та «Еклезіаст».

Підсумовуючи опрацьований матеріал, слід зазначити, по-перше, що, вирісши із республіканського фестивалю музичних прем'єр, котрий попервах тривав не більше трьох днів, наразі «Мельпомена Таврії» має статус міжнародного театрального форуму, який з кожним роком існування підкріплює цей статус і розширює як часові, так і репертуарні межі. Навіть зіткнувшись 3 кризою, коли фестивалеві загрожувала втрата своїх закордонних учасників, а також учасників зі східної України, йому вдалося втриматись на фестивальній арені. Хоча кількість гостей і учасників заходу у 2014 р. різко знизилась, «Мельпомена Таврії» досить швидко поновила свої сили, і через два роки фестиваль вже відвідує рекордна кількість вітчизняних і закордонних учасників.

Репертуар фестивалю, який зароджувався як огляд українських музичних прем'єр, значно розширився за вісімнадцять років і став досить еклектичним. Історія фестивального репертуару насичена настільки різноманітними за жанром, формою, стилем, художнім напрямом виставами, що визначити певну тенденцію у ньому неможливо. У такій ситуації важко зрозуміти, якими критеріями керуються організатори у процесі відбору спектаклів-учасників.

Статистичний аналіз свідчить, що за вісімнадцять років проведення загальна кількість постановок, представлених у межах фестивалю, сягнула 201-ї. Фестиваль відвідали 122 вітчизняних та зарубіжних колективи з 64-х міст. Загалом у фестивалі взяли участь театри з чотирнадцяти країн.

Найпопулярнішими $з$ авторів, за творами яких демонструвались постановки, стали: М. Гоголь (12 постановок), А. Чехов (10 постановок), В. Шекспір (9 постановок), М. Куліш (6 постановок). Лідерами серед п'єс, що були представлені на огляд журі, стали: «Одруження» М. Гоголя (4 рази), «За двома 
зайцями» М. Старицького (3 рази), «Лісова пісня» Лесі Українки (3 рази). Домінантне становище класики в репертуарі фестивалю свідчить про зрілість і високий художній та професійний рівень колективів, які беруть участь у конкурсі.

Переважна кількість театральних колективів, які приїздили на фестиваль, - 3 Києва. Їхня загальна кількість - понад тридцять представників. Загалом статистика свідчить, що найчастіше «Мельпомену Таврії» відвідували: Миколаївський український академічний театр драми та музичної комедії (19 разів), Криворізький академічний театр музично-пластичних мистецтв «Академія руху» (13 разів), Київський національний академічний драматичний театр ім. І. Франка (11 разів). 3-поміж закордонних учасників найчастішими відвідувачами стали Державний молодіжний російський драматичний театр «3 вулиці Роз» 3 Кишинева -7 вистав, Республіканський театр білоруської драматургії з Мінська - 6 вистав, Teatro Circo de Braga 3 Португалії - 4 вистави, Пермський театр «У моста» - 4 вистави [14]. Це досить широкий географічний спектр учасників. Відносно сталий склад учасників фестивалю свідчить про професійну затребуваність і зацікавленість цих колективів брати у ньому участь. Цьому сприяє його ідея, насичена мистецька програма і високий рівень організації проведення самого форуму. На базі театру в усі дні фестивалю працює прес-клуб, де спілкуються представники театрів-учасників, члени журі, журналісти, гості та глядачі, працюють творчі лабораторії для керівників аматорських колективів.

Одноразово «Мельпомену Таврії» відвідали представники 3 таких міст: Сімферополь, Нова Каховка, Севастополь, Чернігів, Ужгород, Житомир, Івано-Франківськ, Полтава, Кіровоград, Біла Церква, Дніпродзержинськ, Чернівці. Учасники з Франції, Ізраїлю та Азербайджану також приїздили лише один раз. За вісмнадцять років існування «Мельпомену Таврії» відвідали театри майже 3 усіх обласних центрів України, окрім Вінниці і Хмельницького, що демонструє потенціал майбутнього співробітництва.

Окремої уваги — як предмет аналітичної розвідки - потребує номінаційна та конкурсна політика фестивалю «Мельпомена Таврії». За всю його історію учасникам було присуджено нагороди у 108 номінаціях, 3 них 18 були представлені від журналістського журі. Парадоксально, але у 78-ми номінаціях дипломи присуджувалися одноразово! Серед них, наприклад, такі: «Виставалегенда», «Відкриття фестивалю», «За втілення європейської драматургії», «За втілення ідей гуманізму та доброти», «За високу культуру пластичного рішення філософських проблем у виставі», «За чесність у професії» та багато інших. При цьому деякі номінації різняться лише назвою, проте суть їх залишається фактично однаковою: наприклад, майже ідентичні номінації «За плідну співпрацю, творчість та високу акторську майстерність» $\mathrm{i}$ «За високу акторську майстерність».

Справляється враження, що організатори свідомо ставлять на меті систематично розширювати перелік номінацій. Цей процес важко виправдати прагненням вдосконалити номінаційний перелік. Щороку організатори створюють все нові й нові номінації. Очевидним стає висновок, що список номінацій щороку носить ситуативний характер - він формується залежно від представлених до конкурсу вистав, їхньої жанрової різноманітності і вражень членів журі від побаченого. Тобто номінації не є заздалегідь визначеними. До прикладу, у 2015 році Є.Нищук отримав нагороду у номінації «За створення сценічного образу героя-романтика» у виставі Київського національного академічного драматичного театру ім. Івана Франка «Момент кохання» - за оповіданням В. Винниченка «Момент». А в 2007 році Київський академічний театр оперети отримав нагороду «За збереження традицій класичного мюзиклу» - за виставу «Моя чарівна леді». Одна з номінацій взагалі є унікальною і неповторною в своєму роді. Це нагорода, яку отримав Микола Берсон, директор Миколаївського українського академічного театру драми та музичної комедії, — «За творчу співпрацю 3 Міжнародним театральним фестивалем “Мельпомена Тавріі” протягом 15 років».

Разом з тим $\epsilon$ номінації, нагороди в яких вручаються майже регулярно, такі як «Краща жіноча роль», «Краща чоловіча роль», «Краща режисура», «Кращий акторський ансамбль», «Краща сценографія», «Краща вистава», «Краща жіноча роль другого плану» та ін.

Найчисленнішою стала нагорода за кращу чоловічу роль - 26 разів, з них двічі нагороджувався актор Херсонського обласного академічного музично-драматичного театру ім. М. Куліша С. Михайлівський: у 2013 році за роль Джиммі у виставі «Продавець дощу» Р. Неша і у 2015 році за роль у моновиставі «Get happy».

Також у номінації «Краща жіноча роль» двічі нагороджувалась акторка знову ж таки Херсонського обласного академічного музично-драматичного театру ім. М. Куліша, заслужена артистка України О. Галл-Савальська: у 2002 
році за роль у виставі «Хелло, Доллі!» Д. Германа i у 2008 році за роль у виставі «Два серця» О. Образцова. До речі, у 2008 році вона отримала цю нагороду двічі - від професійного журі та від журналістського, а в 2007 році журналістське журі також відзначило О. Галл-Савальську як кращу виконавицю жіночої ролі у виставі «Вовки та вівці» О. Островського [15].

Нагороду в номінації «Краща сценографія» двічі отримали Сергій та Наталка Ридванецькі у 2009 році за сценографію у виставі «Страшна помста» М. Гоголя Херсонського обласного академічного музично-драматичний театру ім. М. Куліша та в 2015 році за виставу «Сканінг» за п'єсою Є. Марковського Черкаського академічного обласного українського музично-драматичного театру ім. Т. Г. Шевченка.

У номінації «Краща режисура» тричі був нагороджений С. Павлюк - у 2011 році за виставу «Калігула» А. Камю Рівненського обласного академічного українського музично-драматичного театру, у 2012 році за виставу «На великій дорозі» А. Чехова Херсонського обласного академічного музично-драматичного театру ім. М. Куліша та у 2015 році за виставу «Будинок на кордоні» С. Мрожека цього ж театру.

Двічі в номінації «Кращий акторський ансамбль» був нагороджений колектив Республіканського театру білоруської драматургії з Мінська - у 2006 році за виставу «Адвєчна пєсня» за п’єсою Я. Купали і у 2011 році за виставу «Чайка» за п’єсою А. Чехова.

Загалом, слід зазначити, що майже всі зарубіжні колективи, які коли-небудь відвідували фестиваль, не залишалися обділеними, отримуючи нагороди в тих чи інших номінаціях. Організатори фестивалю цього факту не приховують і обгрунтовують його бажанням налагодити зв'язки 3 театральним зарубіжжям. Тому намагаються зробити приємність закордонним гостям і залишити по собі хороше враження. Однак говорити про цілковиту упередженість та заангажованість журі в оцінці зарубіжних колективів не доводиться. Скоріше можна спостерігати доброзичливе і гостинне ставлення до іноземців. Адже, підводячи підсумки, як свідчать фахівці, журі цілком об'єктивно оцінюе вистави, відзначаючи творчі здобутки $[5,43]$. Так, наприклад, жодного разу не отримали нагороду Національний академічний драматичний театр ім. Якуба Коласа 3 м. Вітебська (Білорусь), хоча він і приїздив двічі - у 2005-му і 2013 роках, Державний російський драматичний театр ім. Чехова 3 м. Кишинів (Молдова), Тамбовський державний драматич- ний театр (Росія), Театр ім. Олександра Севрука 3 м. Ельблонга (Польща), Могилівський обласний театр драми та комедії ім. Дуніна-Марцинкевича 3 м. Бобруйська (Білорусь), Молодіжний театр «Міракль» та Смоленський державний драматичний театр ім. Грибоєдова (Росія), Державний російський драматичний театр Республіки Мордовія $з$ м. Саранська (Росія), Срусалимський театр «Тарантас» 3 Ерусалима (Ізраїль), Teatrul Victor Ion Popa 3 м. Бирлада (Румунія) та Народний театр «Пілайте» 3 Вільнюса (Литва). Загалом із сорока п'яти зарубіжних колективів $27 \%$ повернулися додому ні з чим. При цьому слід зауважити, що з 78-ми українських колективів майже половина теж залишилася без нагород (42\%).

Директор ТОВ «Фестивальний центр» О. Мудрий, один з організаторів фестивалю, в інтерв'ю співавторові цієї публікації А. Вічній щодо колізій навколо існування номінацій і присудження нагород зазначав, що конкурсна основа фестивалю - це нині радше умовність і свого роду архаїзм, певний рудимент, який потихеньку відмирає. Для учасників фестивалю отримання нагороди нібито не має важливого значення, $є$ певною формальністю, проте О. Мудрий тут же навів приклад Пермського театру «У моста», який перестав відвідувати «Мельпомену Таврії», звинувативши організаторів і журі в «кумівстві» і необ'єктивності у присудженні дипломів. 3 цього напрошується висновок, що для деяких номінантів присудження нагороди має неабияке значення, адже надає можливість отримати оцінку своєї роботи, що в свою чергу надихає на подальшу творчість.

О. Велимчаниця стверджує, що принцип організаторів і журі нагородити майже кожного, знайти «вагоме», «активне», «своєрідне», тягне фестиваль вниз, до провінційності. На даному етапі розвитку фестивалю немає потреби в тому, щоб нагороджувати кожного і нікого не образити. Це дорослий конкурс, і змагання найкращих будуть такими тоді, коли нагороджуватимуть найкращих, хоч їх може виявитися і небагато $[16,45]$.

3 історії номінаційної політики фестивалю стає зрозумілим, що до недавнього часу чітких конкурсних позицій не існувало, i журі було схильне вручати нагороди у номінаціях, вигаданих спеціально під конкретний колектив. Це давало змогу майже кожному учасникові отримати диплом, таким чином зводячи конкурсну основу фестивалю до простого огляду мистецьких здобутків. Сьогодні ситуація більш-менш стабілізувалася: визначились номінації, доцільність і необхідність яких перевірена часом, хоча організатори фестивалю подеколи 
продовжують вигадувати нові номінації для деяких конкретних випадків, якщо у жодну з традиційних номінацій вони не вписуються.

Після вивчення номінаційної політики «Мельпомени Таврії», ми опрацювали статистичні дані стосовно кількості номінацій, у яких були вручені нагороди за усі фестивальні роки вітчизняним та зарубіжним колективам. Виявилося, що, окрім традиційних фестивальних номінацій - «Краща вистава», «Гран-прі», «Кращий актор/актриса», «Краща режисура» і т. д., оргкомітет та журі щоразу винаходять нові номінації, бажаючи відзначити учасників за той чи інший здобуток у конкретних виставах. Зважаючи на еклектичність репертуарної політики фестивалю, можна зробити висновок, що такий підхід до створення номінацій нівелює їхню вагомість і позбавляє фестиваль жорсткого конкурсного відбору. Адже розуміння поняття «бути найкращим» підмінюється поняттям «бути єдиним».

Підсумовуючи результати аналізу організаційно-творчої діяльності, зокрема репертуарної політики фестивалю «Мельпомена Таврії», можна стверджувати, що він засновувався як фестиваль українських музичних прем'єр, але у процесі еволюції заходу організатори відмовляються від такого визначення його жанрового напряму. Наразі художня концепція цього заходу не є чітко окресленою, а отже еклектичною за своєю суттю, адже на фестиваль запрошуються настільки різноманітні за жанром, формою, стильовим і естетичним спрямуванням вистави, а також колективи різних видів мистецької діяльності і професійної підготовки, що визначити тенденцію та критерії у відборі фестивальних робіт фактично неможливо. 3 іншого боку, така насиченість репертуару $є$ перевагою, оскільки дає можливість глядачам та учасникам побачити виставу на будь-який смак, а також познайомитися з суміжними до театрального видами мистецтва.

«Мельпомена Таврії» має гарні перспективи для подальшого розвитку. За вісімнадцять років існування лише у 2014 році відбувся помітний спад у кількості учасників фестивалю через суспільно-політичні проблеми в Україні. Однак, починаючи з наступного року, фестиваль швидко набирає обертів, і вже у 2016 р. на ньому фіксується рекордна кількість представлених спектаклів. Це свідчить про наявність потужної організаторської команди та їі вміння підтримувати авторитет свого заходу як на вітчизняному, так і на світовому ринку. При такій швидкості прогресування та при наявності в майбутньому стабільного фінансуван- ня фестиваль має всі шанси вийти на рівень масштабних європейських форумів.

Проведене дослідження не вичерпує всіх аспектів проблематики. Серед перспектив подальшого вивчення «Мельпомени Таврії» у системі фестивального театрального руху — аналіз досвіду проведення світових міжнародних театральних фестивалів, їхнього впливу на розвиток театрального мистецтва в Україні та місця «Мельпомени Таврії» у цьому процесі.

\section{Джерела та література}

1. Мірошниченко Н. Театр у пошуках музичності [Текст] / Н. Мірошниченко // Кіно-Театр. - 2001. № 6. - C. 26.

2. Косянчук І. Сюрпризи «Мельпомени Таврії» [Текст] / І. Косянчук // Урядовий кур'єр. - 2002. 27 червня. - С. 10.

3. Шевченко Л. Мельпомена Таврії - здалеку і зблизька [Текст] / Л. Шевченко // Український театр. 2005. - № 1-2. - С. 6-8.

4. Натяжна А. «Мельпомена» - муза перевірена [Текст] / А. Натяжна // День. - 2005. - 14 липня. C. 7.

5. Шевченко Л. Свято єдності [Текст] / Л. Шевченко // Кіно-Театр. - 2006. — № 5. - С. 41-43.

6. Подлужная А. На балу у Мельпомены Таврической [Текст] / А. Подлужная // Киевские ведомости. 2006. - 1 июля. - С. 14.

7. Погрібна А. Фестиваль друзів [Текст] / А. Погрібна, О. Велимчаниця // Кіно-Театр. - 2008. № 5. - C. 43-46.

8. Распутіна В. Перший ювілей «Мельпомени Таврії» [Текст] / В. Распутіна // Український театр. 2008. - № 5. - С. 15-16.

9. Шашко С.Враження - назавжди! [Текст] / С. Шашко // Просценіум. — 2009. — №1-2. — С. 140-145.

10. Максименко С. «Мельпомена Таврії 2010» - учасники і переможці [Текст] / С. Максименко // Просценіум. - 2010. - № 2-3. - С. 208-212.

11. Велимчаниця О. Класика і новаторство на таврійській сцені [Текст] / О. Велимчаниця, М. Тетерюк // Кіно-Театр. - 2012. - № 5. - С. 37-40.

12. Цимбал Г. Інтенсивна театротерапія «Мельпомени Таврії» [Текст] / Г. Цимбал // Український театр. - 2013. - № 6. - С. 50-53.

13. Цимбал Г. Час випробування [Текст] / Г. Цимбал // Український театр. - 2014. - № 3. - С. 44-47.

14. Міжнародний театральний фестиваль «Мельпомена Таврії» [Електронний ресурс] : Режим доступу: melpomena.ks.ua. - Назва з домашньої сторінки Інтернету.

15. Шевченко Л. Мельпомена у вирі жанрів і стилів: «Мельпомена Таврії» - 10 років [Текст] / Л. Шевченко // Культура і життя. — 2008. — 7 жовтня (№ 4142). - C. 4.

16. Велимчаниця О.Коли у Херсон приходить «Мельпомена» [Текст] / О. Велимчаниця, А. Погрібна // Кіно-Театр. — 2010. — № 5. - С. 42-45. 